\title{
Studi ruang rumah tinggal masyarakat Bali Katolik di Desa Canggu
}

\author{
Jesica Angelia Putra ${ }^{1}$, Naniek Kohdrata ${ }^{1 *}$, I Dewa Gede Agung Diasana Putra² \\ 1. Program Studi Arsitektur Pertamanan, Fakultas Pertanian, Universitas Udayana, Indonesia 80232 \\ 2. Program Studi Arsitektur, Fakultas Teknik, Universitas Udayana, Indonesia 80232 \\ *Email: naniek kohdrata@unud.ac.id
}

\begin{abstract}
Study of residential space of the Catholic Bali Community at the Canggu Village. Balinese culture is a complex phenomenon based on various beliefs such as Hinduism, Shiva, Buddhism and combined with ancestral traditions therefore that Bali has a special uniqueness of the ceremonial activities performed and the architecture of the building. Over time, the many interactions that enter Bali cause interactions between communities, resulting in friction between cultures which allows acculturation to occur. One of the cultural meetings that took place in Bali was the existence of a Balinese Catholic community in Canggu Village, North Kuta District, Badung Regency, Bali. Cultural meetings that take place in this village involve Balinese Hindu culture and Catholic traditions. The purpose of this study is to study the picture of cultural encounters that occur in the pattern of Catholic Balinese residences in Canggu Village. The results obtained are that the laying of each building does not consist of one building such as a traditional Balinese house, but does not adapt to the space of the mandala, at a level that adapts the concept of the tri mandala all facing towards the main road.
\end{abstract}

Keywords: acculturation, Balinese Catholic, cultural meetings, spatial pattern

\section{Pendahuluan}

Kebudayaan orang Bali merupakan fenomena kompleks yang dilandasi berbagai kepercayaan seperti; Hindu, Siwa, Budha dan berpadu dengan tradisi leluhur. Oleh karena itu penyembahan roh-roh, nenek-moyang, dan unsur-unsur alam digabungkan dengan ajaran Hindu dan sebuah falsafah yang bernama Tri Hita Karana. Masyarakat Bali juga mendasarkan pada nilai-nilai agama Hindu dan falsafah Tri Hita Karana. Falsafah hidup Tri Hita Karana sangat menekankan adanya keharmonisan dan keseimbangan hidup antara manusia dengan manusia, manusia dengan Sang Pencipta, dan manusia dengan lingkungannya.

Banyaknya kebudayaan asing yang masuk ke Bali akibat interaksi antar masyarakat menyebabkan adanya pergesekan antar budaya yang terjadi sehingga memungkinkan timbulnya akulturasi dan asimilasi. Salah satu pertemuan budaya yang terjadi di Bali adalah adanya masyarakat Bali Katolik di Desa Canggu Kecamatan Kuta Utara, Kabupaten Badung, Bali.

Pertemuan budaya yang terjadi pada desa ini melibatkan kebudayaan Hindu Bali dan tradisi Katolik. Adanya tuntutan untuk beradaptasi dengan lingkungan yang dihadapi sehingga masyarakat Katolik di Desa canggu tersebut membutuhkan usaha-usaha untuk menstabilkan keadaan dan memperkecil perbedaan-perbedaan dari kedua belah pihak. Cara yang digunakan oleh masyarakat Katolik ini adalah dengan melakukan integrasi pada sistem sosial yang sudah ada maupun adaptasi budaya lokal (Hindu Bali) kedalam budaya Katolik termasuk di dalamnya adalah adaptasi arsitektural bagunan tempat ibadah (gereja) dan tempat tinggal yang digunakan oleh masyarakat Hindu Bali. Tujuan studi ini untuk mengetahui pertemuan budaya yang terjadi pada ruang rumah tinggal Masyarakat Bali Katolik di Desa Canggu.

\section{Metode}

Penelitian ini dilakukan di Desa Canggu, Kecamatan Kuta Utara, Kabupaten Badung, Bali. Penelitian ini hanya dilakukan pada dua banjar adat, yakni Banjar Padang Tawang dan Banjar Babakan. Keduia banjar ini dipilih karena lokasi tersebut adalah awal terbentuknya masyarakat Bali Katolik di Desa Canggu. 
Penelitian ini memakai metode kualitatif dengan pendekatan kebudayaan. Populasi dalam penelitian ini mencakup seluruh rumah tinggal Masyarakat Bali Katolik di lokasi penelitian. Pengambilan sampel untuk observasi yaitu memakai teknik purposive sampling dengan cara menetapkan ciri-ciri khusus yang sesuai dengan tujuan penelitian sehingga diharapkan dapat menjawab permasalahan penelitian. Sampel yang dipakai adalah rumah tinggal masyarakat Bali Katolik (bukan pendatang) yang pekarangannya memiliki luas lahan lebih besar dari $150 \mathrm{~m}^{2}$. Adapun langkah yang dilakukan dalam memperoleh data yaitu: (1) wawancara terhadap masyarakat Bali dengan kepercayaan Katolik yang tinggal dan masyarakat asli (bukan pendatang) di Desa Canggu, (2) membuat sketsa denah rumah tinggal masyarakat Bali Katolik , dan (3) studi literatur.

\section{Hasil dan Pemahasan}

\subsection{Gambaran umum}

Desa Canggu secara administratif terletak di kecamatan Kuta Utara, Kabupaten Badung, Provinsi Bali, yang merupakan sebuah desa pesisir pantai dengan jarak 12,9 km dari kota Denpasar. Secara geografis Desa Adat Canggu terletak antara 8014'20" - 8050'52" LS dan 115005'03" - 115026'51" BT dengan luas wilayah 5,23 $\mathrm{Km}^{2}$ (Gambar 1). Desa Adat Canggu dibagi menjadi tujuh banjar adat yaitu: (1) Banjar Padang Tawang, (2) Banjar Babakan, (3) Banjar Umabuluh, (4) Banjar Kayutulang (5) Banjar Pipitan (6) Banjar Padang Linjong, dan (7) Banjar Canggu.

Penduduk di Banjar Padang Tawang dan Banjar Babakan yang tercatat pada data, adalah masyarakat yang memeluk agama Katolik terbesar di Desa Canggu dengan presentase $41,1 \%$ di Banjar Padang Tawang dan 55,5\% di Banjar Babakan dari seluruh penduduk Katolik di Desa Canggu.

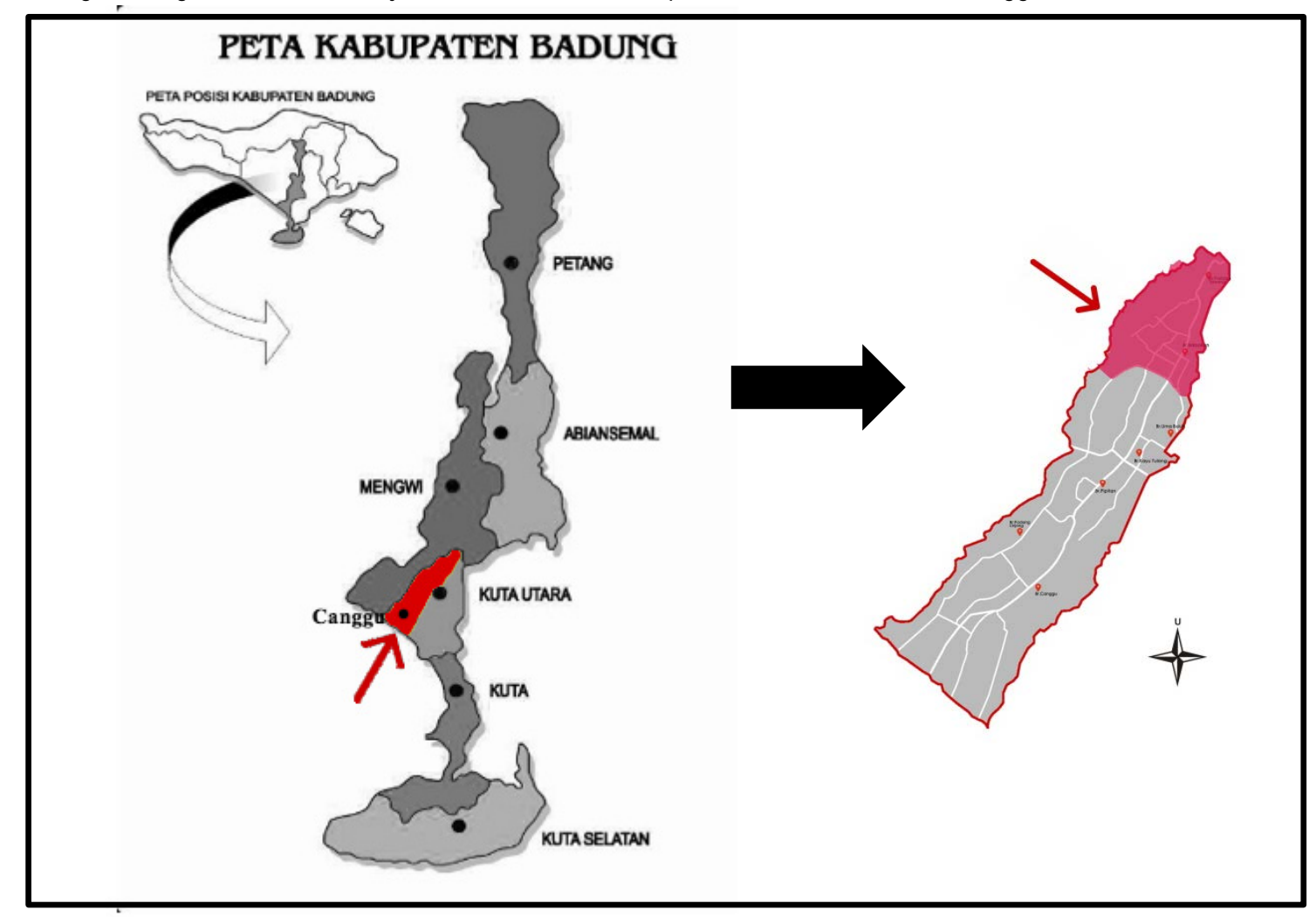

\subsection{Sejarah Masyarakat Katolik di Desa Canggu}

\section{Gambar 1. Lokasi Penelitian}

Penyebaran awal kepercayaan Katolik di Pulau Bali dimulai tahun 1935 melalui para misionaris dari benua Eropa. Sejarah Gereja Katolik di Bali bermula pada tahun 1935, persisnya 11 September 1935, Pater Van Der Heijden mengantar Pater J. Kersten SVD ke Denpasar dan mulai menetap di Denpasar. Hal tersebut diyakini sebagai awal perkembangan agama Katolik di Bali. Desa Tuka menjadi tempat awal penyebaran Katolik di Bali. Diceritakan bahwa sekitar tahun 1935, pertemuan terjadi antara I Made Bronong 
(Pan Regig) dan I Wayan Diblug (Pan Rosa) dengan Pater J. Kersten SVD dimana mereka merupakan pemuda asli Banjar Tuka. Dari dua orang tersebut, umat Katolik di Tuka berkembang menjadi 12 orang dan menyebar di tempat lain seperti Banjar Babakan, Banjar Padang Tawang dan Kulibul di Badung, hingga Desa Palasari di Wilayah Kabupaten Jembrana yang merupakan masyarakat wilayah Bali asli yang memeluk agama Hindu.

Dahulu pemuda di Desa canggu memiliki kebiasaan sering melakukan kunjungan ke rumah pemudi yang dikenal dengan bahasa bali yaitu nganggur. Awal mula sekitar tahun 1940, I Made Bronong mendatangi rumah I Wayan Redug untuk nganggur, ia juga menjalankan tugasnya sebagai misionaris yaitu memberitakan injil. Singkat cerita, dialog yang mereka lakukan lama-kelamaan menjadi suatu ajaran dan keyakinan agama yang menjadikan I Wayan Redug memutuskan untuk menjadi Kristen Katolik, sehingga sesungguhnya I Wayan Redug menjadi orang pertama di Desa Canggu yang memeluk agama Kristen Katolik. I Wayan Redug kemudian menawarkan rumahnya untuk dijadikan tempat belajar agama. Keterbatasan I Wayan Redug yang tidak bisa membaca dan menulis, menjadi sebuah kendala yang cukup besar karena ia menjadi sulit untuk memahami ajaran yang diberikan oleh misionaris tersebut karena semua inti dari pengajaran dan injil ada di kitab suci (Alkitab) dimana ia dituntut untuk bisa mandiri dalam pendalaman pemahaman mengenai kitab suci tersebut. Akhirnya I Wayan Redug meminta bantuan kepada keponakannya, yaitu I Nyoman Regeg untuk mendampingi misionaris tersebut sekaligus menjadi ketua kelompok pendalaman kitab suci (Alkitab) di wilayah Bajar Padang Tawang. Ketertarikan I Nyoman Regeg terhadap ajaran agama tersebut membuat ia memeluk agama Katolik. la sekaligus menjadi orang pertama yang dibaptis dan menjadi orang Katolik yang sah dengan nama Arnoldus I Nyoman Regeg (Pan Maria). Sejak saat itu mulai muncul benih-benih umat Katolik di Desa Canggu, khususnya Banjar Padang Tawang dan Babakan (Anonim, 2011).

\subsection{Pertemuan Kebudayaan Masyarakat Bali Katolik di Desa canggu dengan Hindu Bali}

Koentjaraningrat (2012) mengatakan bahwa ada hal-hal yang perlu diperhatikan dalam proses akulturasi sebaiknya mengandung beberapa hal tersebut saat melakukan penelitian, yakni (1) keadaan sebelum proses akulturasi tersebut, (2) para induvidu pembawa unsur-unsur kebudayaan asing, (3) saluransaluran yang dilalui oleh unsur-unsur kebudayaan asing untuk masuk ke dalam kebudayaan penerima, (4) bagian-bagian dari masyarakat yang terkena pengaruh dan, (5) reaksi para induvidu yang terkena unsurunsur kebudayaan asing.

Berdasarkan poin-poin proses terjadinya akulturasi di atas, proses terjadinya akulturasi budaya Katolik dan Hindu di Desa Canggu berawal dari tahun 1935 melalui para misionaris dari benua Eropa. Desa Tuka menjadi ladang awal penyebaran Katolik di Bali dan berkembang serta menyebar di seluruh wilayah Bali. Pengaruh dari adanya kebudayaan Katolik bagi masyarakat Bali di Desa Canggu dapat dilihat pada sistem sosial, peribadatan dan aritektur tempat tinggal mereka.

Tempat tinggal pada masyarakat Bali adalah ruang untuk menampung aktivitas manusia yang diturunkan dari generasi ke generasi dengan perubahan-perubahan yang menyesuaian dengan perkembangan zaman serta berdasarkan norma-norma yang berlaku, peraturan traditional (Asta Kosala Kosali), adat kebiasaan setempat dan bergantung pada kondisi serta potensial alam dan lingkungan. Sama halnya dengan rumah tinggal masyarakat Bali, rumah tinggal masyarakat Katolik Desa Canggu sebagian besar tidak merupakan satu kesatuan dalam satu atap tetapi terbagi dalam beberapa ruang dan berdiri sendiri dalam pola ruang pekarangan rumah dan diatur menurut konsep arah sumbu gunung hulu-teben, dimana kaja yang dianggap suci oleh orang Bali sendiri. Hal ini terjadi karena hirarki yang ada menuntut adanya perbedaan fungsi ruang dan kedudukan ruang. Seperti halnya bangunan utama yaitu ruang tidur terpisah dengan dapur, dan juga hubungan antara dapur dan tempat pemujaan keluarga. Namun ada ditemukan beberapa rumah yang bangunan utama dan dapur berada pada satu kesatuan disebabkan oleh lahan yang cukup sempit sehingga tidak memungkinkan untuk membangun setiap ruang secara terpisah.

Area pekarangan rumah masyarakat Katolik di Desa Canggu memakai tiga pembagian zona ruang berdasarkan jenis ruangnya seperti yang dikenal dalam istilah Bali sebagai konsep tri mandala. Ketiga area tersebut dikenal dengan nama nista mandala sebagai area terluar seperti telajakan dan teba. Telajakan merupakan sebagian jalan raya atau jalan kampung yang ada di depan atau samping pekarangan rumah yang umumnya di tanami tanaman, dan teba adalah pekarangan yang ada di belakang rumah. Area 
peralihan atau area trasisi merupaan zona yang bernilai semi sakral atau disebut dengan madya mandala seperti natah, banguanan utama, dan bale. Zona terakhir adalah zona yang paling sakral yaitu area utama mandala dimana zona ini ditempatkan Gua Bunda Maria. Pembagian zona ruang masyarakat Katolik pada umumnya didasari dengan ajaran teologis dalam penataan ruang gereja umat Katolik. Seperti halnya konsep tri mandala, pembagian zona ruang gereja Katolik juga dibagi atas tiga zona. Area pintu masuk yang disebut narthex sebagai area terluar. Narthex menandai langkah pertama dalam transisi dari dunia luar menuju surga (tempat kudus). Itu harus menjadi tempat masuk, menyambut orang-orang yang mencari perlindungan, pelipur lara, kasih dan kebenaran. Adapun elemen yang ada dalam ruang ini adalah patung, signage, kamar mandi. Bagian tengah gereja atau nave membentang dari pintu masuk hingga bagian tersakral gereja yang terdapat mimbar dan altar yaitu sanctuary. Nave biasanya merupakan bagian terbesar dari Gereja, daerah di mana orang duduk di bangku yang letaknya di antara teras (narthex) dan tempat kudus (Sanctuary). Berasal dari bahasa Latin navis (kapal atau bahtera), itu adalah tempat berlindung dari kekacauan yang bergolak. Sanctuary merupakan area khusus Gereja yang mengelilingi altar di mana upacara paling penting yaitu Misa diadakan. Dianggap sebagai tempat kudus, dan telah dipahami sebagai mikrokosmos surga yang di letakan dengan cara khusus (Gambar 2).

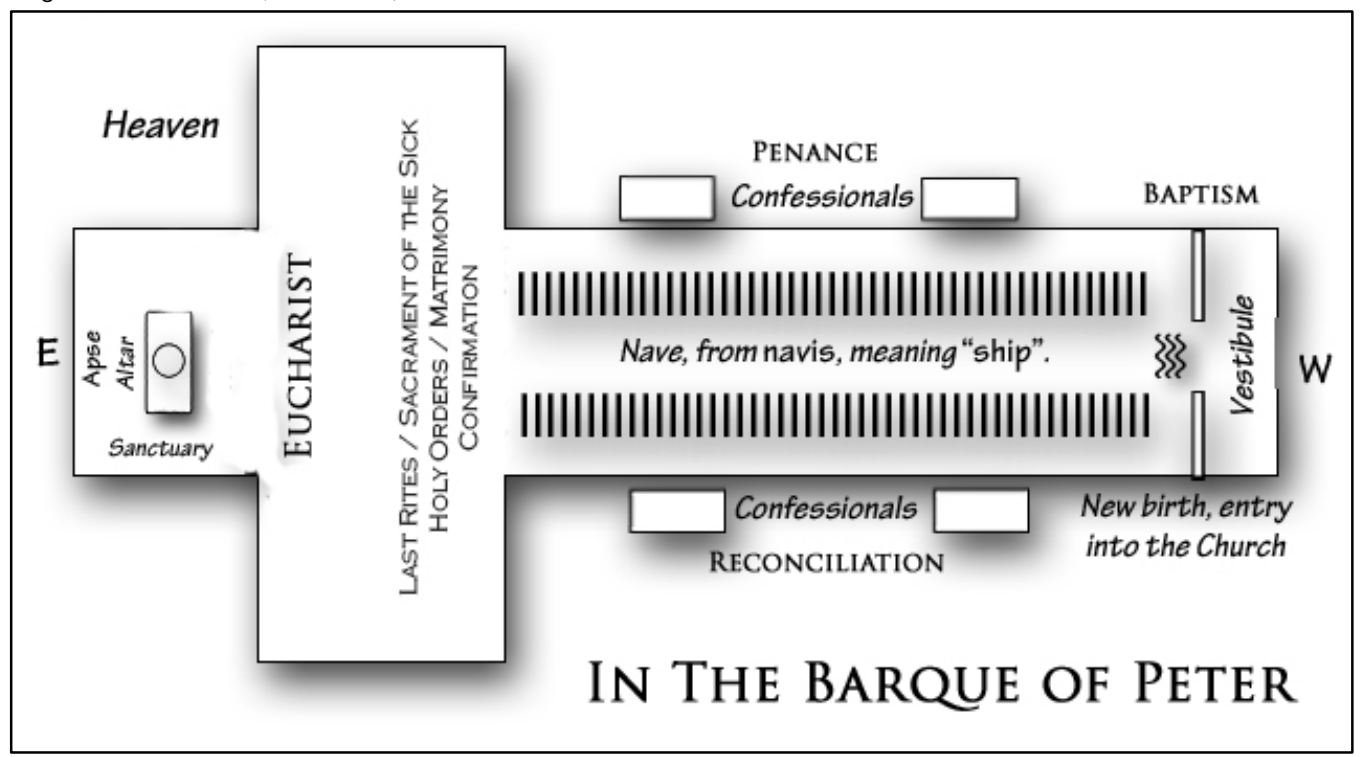

Gamber 2. Pola Ruang Arsitektur Gereja Katolik (Srisadono, 2012)

Masyarakat Bali pasti melakukan acara sosial dan upacara adat persembahyangan saat rahinan (hari yang di anggap suci). Berbagai kegiatan ini dilakukan di rumah. Maka rumah adat Bali harus mempunyai tempat khusus untuk acara ini, biasanya bale gede, dan bale semanggen. Kalau masih kurang bisa dibuatkan lagi bangunan darurat dengan atap kelangsah (daun kelapa dianyam) yang disebut rerompok. Kompleks perumahan adat Bali umumnya memiliki ruangan khusus terbuka yang bisa dipakai untuk tempat duduk bertimpuh/bersila. Oleh karena itu rumah-rumah adat Bali biasanya menyediakan sebuah bangunan yang tidak tertutup.

Masyarakat Katolik memiliki waktu khusus untuk mengadakan ibadah misa bersama di rumah salah seorang jemaat gereja dimana pemilik rumah terdaftar. Ibadah ini dilakukan secara bergilir pada setiap jemaat, sehingga masyarakat Katolik pada umumnya memiliki area khusus baik itu dalam bentuk bangunan maupun area tidak terbangun pada pekarangan untuk kegiatan peribadatan dan sosial. Upacara keagamaan lain yang wajib dilakukan oleh pemilik rumah adalah melaspas baik untuk bangunan baru maupun Gua Bunda Maria yang terbangun di area pekarangan pemilik rumah. Penyucian sebuah bangunan atau masyarakat Bali menyebutnya dengan istilah melaspas (dalam hal ini mengenai pekarangan rumah) termasuk katagori sakramentali, yang seperti halnya dengan sakramen, dimaksudkan untuk menguduskan setiap kejadian penting di dalam hidup umat beriman (diatur dalam Konsili Vatikan II tentang Liturgi Suci).Adaptasi lain terlihat dari arsitektur bangunannya, baik itu tempat peribadatan maupun rumah tinggal 
masyarakat Katolik tersebut. Contohnya Gereja mengadaptasi pola pelataran seperti yang terdapat di purapura di Bali. namun jika dilihat lebih jelas terdapat perbedaan antara pura dan gereja. Perbedaan yang paling menonjol ialah jika pada kori agung pura terdapat karang Boma (Gambar 3) yang berfungsi sebagai penglukatan. Sedangkan pada kori agung di gereja tidak terdapat karang Boma melainkan salib dan merpati yang melambangkan agama Kristen sendiri (Gambar 4).

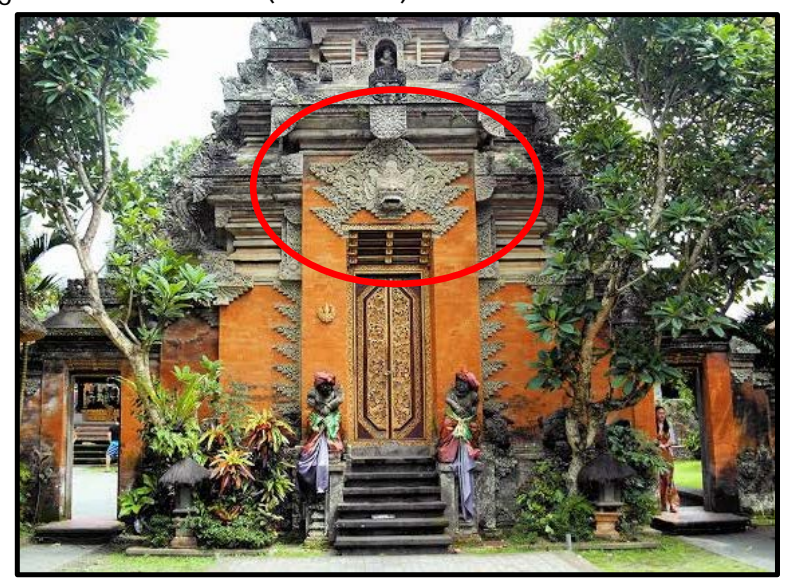

Gambar 3. Karang Boma pada Pura

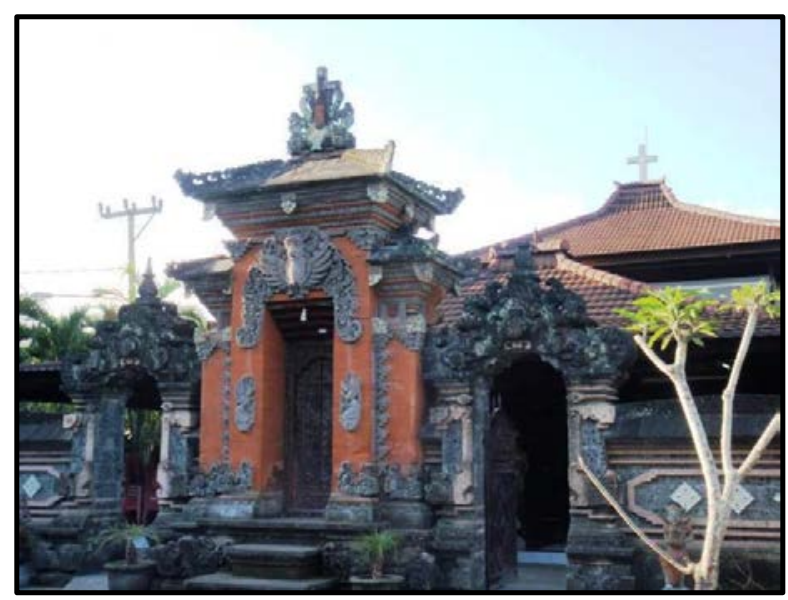

Gambar 4. Candi Bentar pada Gereja Katolik Tri Tunggal Maha Kudus, Tuka

\subsection{Pola ruang rumah tinggal masyarakat Katolik di Desa Canggu}

\subsubsection{Letak}

Rumah masyarakat Katolik di Desa Canggu mencerminkan rumah tradisional Bali, terdiri dari banyak massa bangunan dengan fungsinya masing-masing. Konsep sanga mandala adalah pembagian ruang ke dalam sembilan zona yang lahir dari aplikasi konsep tri angga dalam bidang vertikal dan horisontal, di mana ruang di tengah-tengah sebagai pusat dan simbol sumber kekuatan dibiarkan kosong (konsep catuspatha) (Bappeda, 1982). Konsep tri angga membagi bidang atau sumbu vertikal orientasi kosmologis kaja-kelod dalam tiga zona ruang: utama, madya dan nista, sementara bidang atau sumbu horisontal orientasi tata nilai sakral kangin-kauh juga dibagi dalam tiga zona ruang: utama, madya dan nista (Aler, 1983). Kombinasi pembagian bidang vertikal dan horisontal ke dalam tiga zona ruang yang hirarkis, secara keseluruhan, menghasilkan sembilan zona ruang (Gambar 5). 


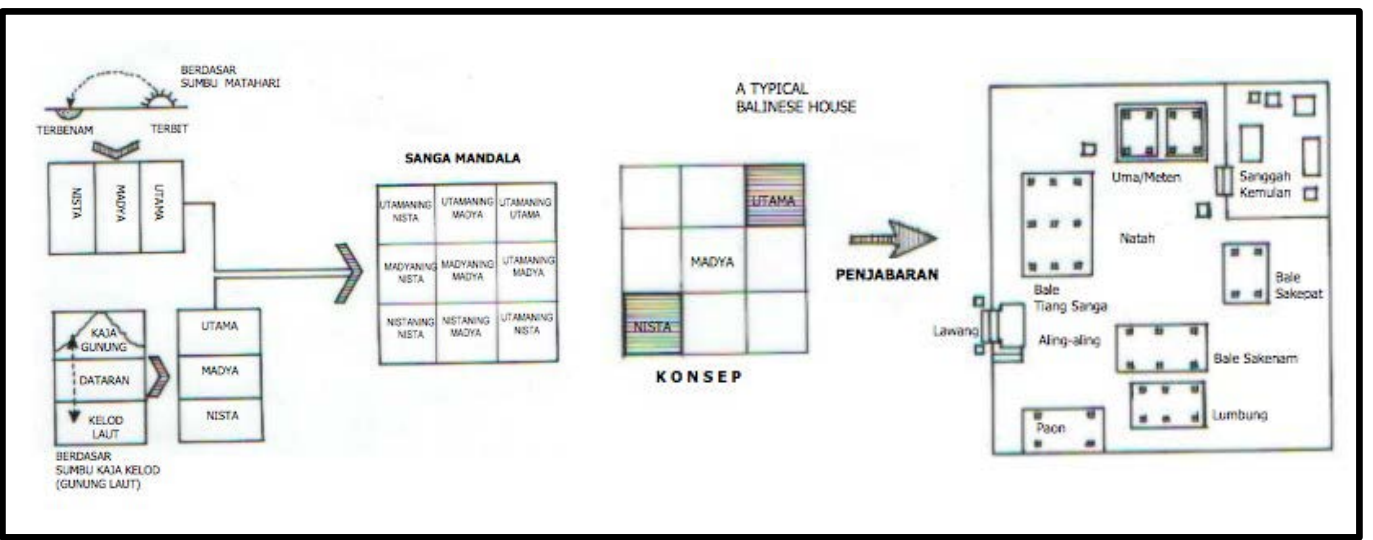

Gambar 5. Penjabaran Konsep Zoning Sanga Mandala dalam Rumah (Eko Budihardjo,1986)

Pada rumah masyarakat Katolik, letak elemen ruang dalam pola spasial yakni jika rumah menghadap kearah timur, pembagian sembilan zona pekarangan (1) kaja (utara) letak kamar tidur orang tua dan beberapa variasinya adalah letak Gua Bunda Maria, (2) kaja-kangin (timur laut) letak Gua Bunda Maria variasinya adalah letak gerbang masuk, (3) kangin (timur) letak gerbang rumah serta beberapa rumah dibangun tempat usaha seperti warung dan bangkel, (4) kelod-kangin (tenggara) letak gerbang rumah variasinya adalah natah, (5) kelod (selatan) letak ruang hunian variasinya adalah akses penghuni untuk keluar atau memasuki rumah, (6) kelod-kauh (barat daya) letak kamar mandi dan variasinya adalah garasi dan dapur,(7)kauh (barat) letak dapur dan variasinya adalah natah dan kamar mandi (8)kaja-kauh (barat laut) adalah letak ruang hunian, (9) bagian tengah untuk pekarangan rumah yang memiliki ruang yang cukup akan digunakan sebagai natah dah beberapa dibangun bale untuk tempat berkumpul. Jika rumah yang tidak memiliki ruang yang cukup maka bagian tengah akan digunakan (Gambar 6).

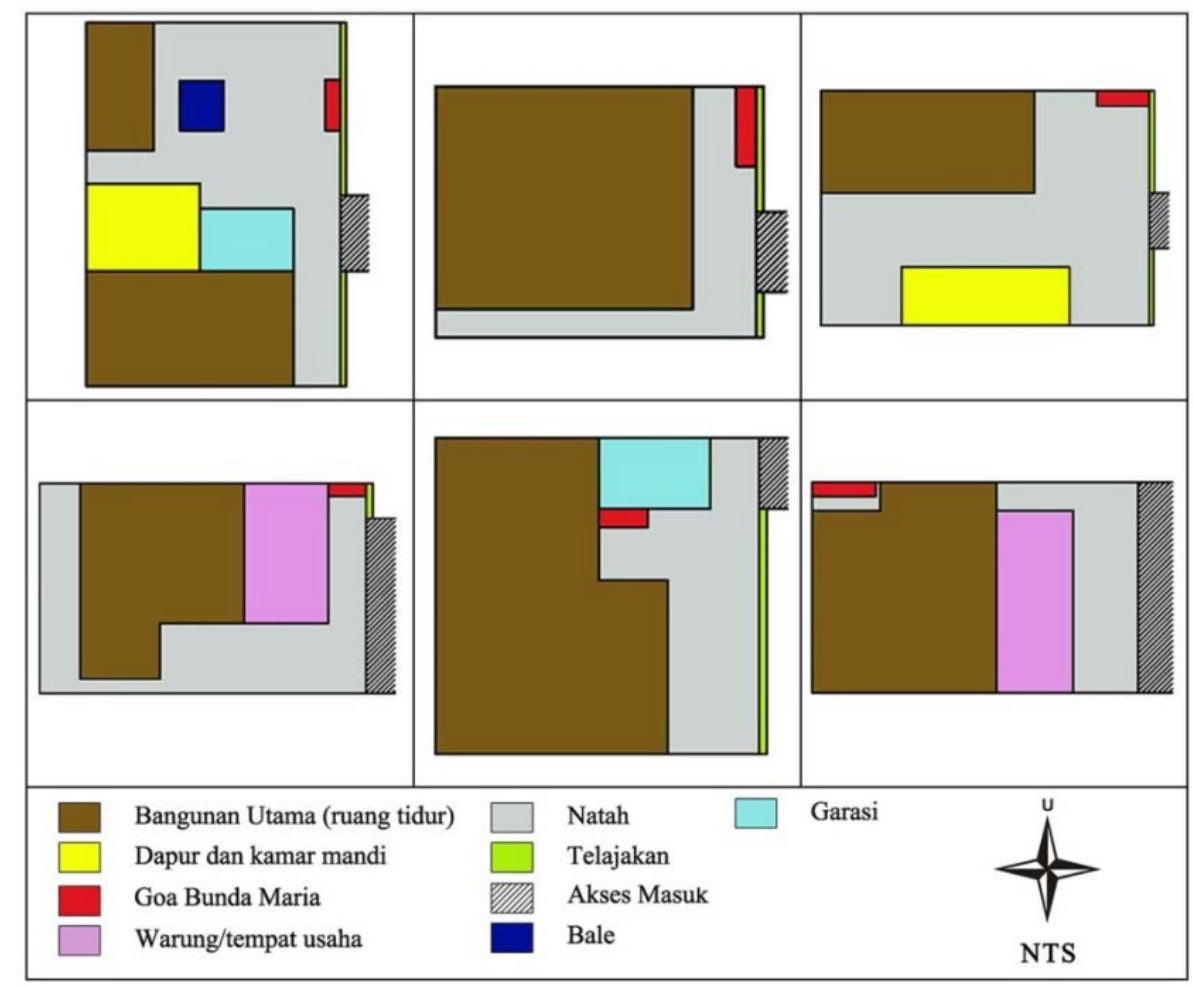

Gambar 6. Pola Ruang Rumah Masyarakat Katolik Desa Canggu Menghadap Timur 
Jika rumah menghadap kearah barat maka pembagian ruang dengan sembilan zona adalah sebagai berikut: (1) kaja (utara) letak ruang hunian dan beberapa variasinya adalah letak Gua Bunda Maria dan bale, (2) kaja-kangin (timur laut) letak natah dan variasinya adalah Gua Bunda Maria, (3) kangin (timur) letak Gua Bunda Maria dan variasinya adalah natah, (4) kelod-kangin (tenggara) letak ruang hunian dan variasinya adalah dapur, (5) kelod (selatan) letak ruang hunian, (6) kelod-kauh (barat daya) letak ruang hunian dan variasinya adalah natah dan gerbang masuk rumah, (7) kauh (barat) adalah ruang kosong sebagai akses keluar masuki penghuni rumah dan letak gerbang rumah, (8) kaja-kauh (barat laut) adalah letak ruang kosong dan variasinya adalah letak Gua Bunda Maria dan natah, (9) bagian tengah untuk beberapa rumah masyarakat Katolik di Desa Canggu, diletakan Gua Bunda Maria serta pekarangan rumah yang memiliki ruang yang cukup akan digunakan sebagai natah dah beberapa dibangun bale untuk tempat berkumpul. Jika rumah yang tidak memiliki ruang yang cukup maka bagian tengah akan digunakan sebagai ruang hunian (Gambar 7).

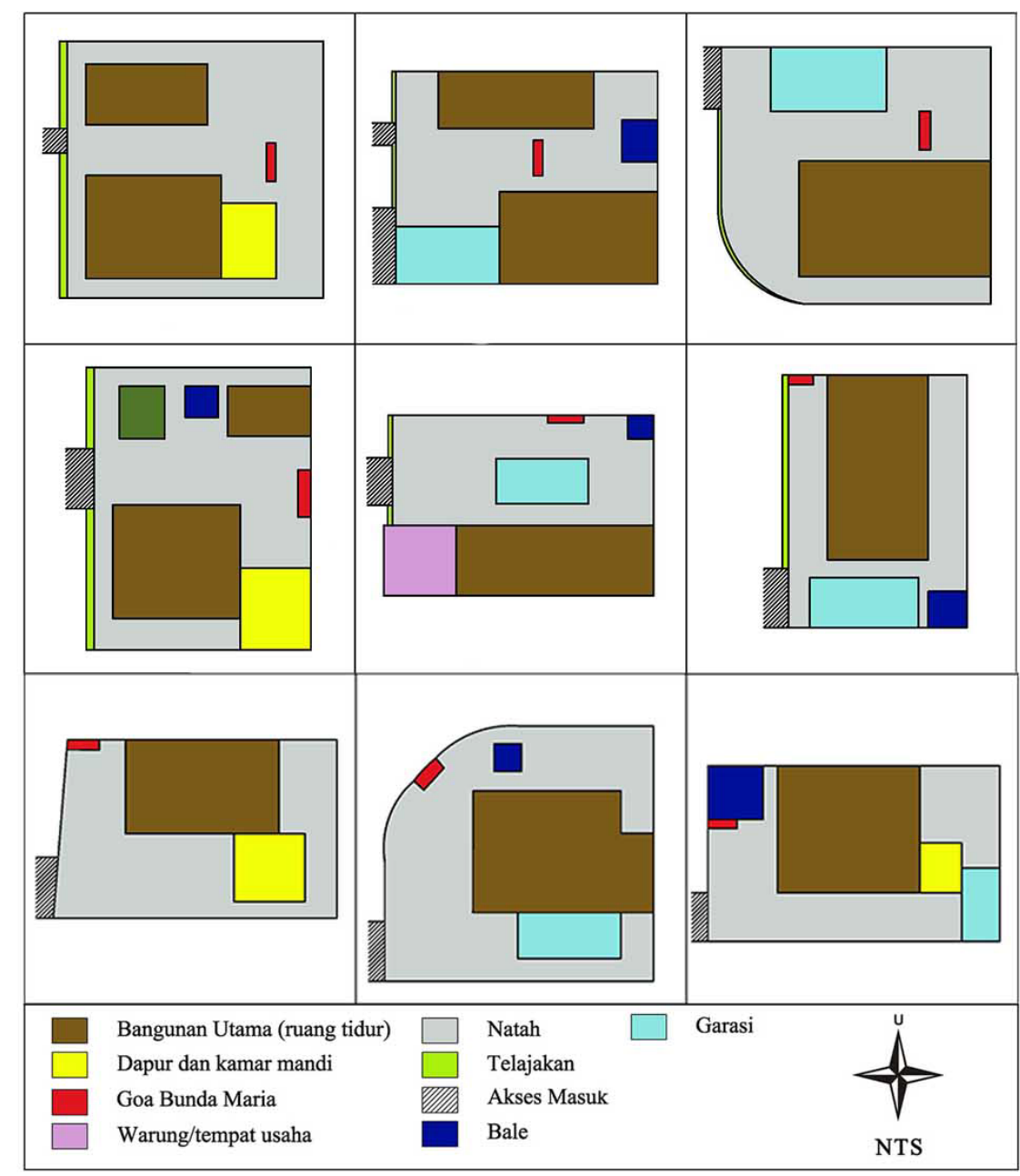

Gambar 7. Pola Ruang Rumah Masyarakat Katolik Desa Canggu Menghadap Barat

\subsubsection{Tingkatan}

Gereja Katolik menekankan dasar teologis dalam setiap pendirian bangunan gereja; fungsi liturgial menjadi landasan utama penataan ruang dan bentuk arsitektur gereja Katolik, baik di masa sebelum maupun sesudah Konsili Vatikan II. Sehingga pada gereja Katolik yang inkulturatif pun, fokus ruang selalu pada sanctuary di mana Ekaristi Kudus dipersembahkan; sehingga area ini menjadi area tersakral dalam tatanan ruang gereja. Umat mengikuti perayaan Ekaristi Kudus di bagian tengah gereja (nave), yang membentang dari pintu masuk (narthex) ke bagian yang paling sakral mimbar di area altar (sanctuary) (Srisadono, 2012). 
Sehingga hal ini serupa dengan konsep tri mandala, pembedanya adalah dalam ajaran Katolik tidak mempersoalkan tata letak berdasarkan arah mata angin dan hanya menekankan pada pembagian pola ruang.

Tiga nilai ruang dalam arsitektur tradisional Bali yang mengandung jenis ruang (sakral, kurang sakral, dan tidak sakral) dan fungsi ruang (Manusia dengan Tuhan, Manusia dengan manusia, dan manusia dengan lingkungan) ditransformasikan dalam arsitektur rumah masyarakat Katolik di Desa Canggu menggunakan konsep hirarki dalam pola spasial dengan tingkatan ruang yang jelas, memperlihatkan adanya gradasi berurut dari kaja ke kelod atau kangin ke kauh yang menunjukkan adanya perbedaan pada peran fungsional dengan pembagian tiga ruang. Gereja Katolik menekankan dasar teologis dalam setiap pendirian bangunan gereja; fungsi liturgial menjadi landasan utama penataan ruang dan bentuk arsitektur gereja Katolik, baik di masa sebelum maupun sesudah Konsili Vatikan II. Sehingga pada seluruh gereja Katolik fokus ruang selalu pada sanctuary di mana Ekaristi Kudus dipersembahkan; sehingga area ini menjadi area tersakral dalam tatanan ruang gereja. Umat mengikuti perayaan Ekaristi Kudus di bagian tengah gereja yang (nave), yang membentang dari pintu masuk (narthex) ke bagian yang paling sakral mimbar di area altar (sanctuary) (Srisadono, 2012). Sehingga hal ini serupa dengan konsep tri mandala, pembedanya adalah dalam ajaran Katolik tidak mempersoalkan tata letak berdasarkan arah mata angin dan hanya menekankan pada pembagian pola ruang.

Secara keseluruhan tingkatan dalam pola spasial membentuk kategori ruang, meliputi nilai dan sifat ruang. Tiga tingkatan nilai ruang dalam pola spasial, meliputi (1) ruang suci yaitu letak Gua Bunda Maria yang berada di area kaja atau kangin, (2) ruang madya adalah ruang kosong atau natah yang berada di posisi ditengah atau dekat dengan ruang hunian dan letaknya daerah kelod atau kauh; (3) dan ruang nista adalah area gerbang ke bagian luar pekarangan, seperti ruang usaha (warung, bengkel dan lain-lain) dan arahnya sesuai dengan posisi rumah.

\subsubsection{Orientasi}

Ruang hunian masyarakat Bali Katolik di Desa Canggu sendiri menghadap kearah jalan desa (Gambar 8). Letak rumah menghadap kejalan desa ini untuk menciptakan adanya hubungan komunikasi dengan tamu yang akan datang kerumah (open space) juga sebagai ruang terbuka ke arah jalan utama dengan maksud agar penghuni rumah bisa mengetahui kedatangan tamu.

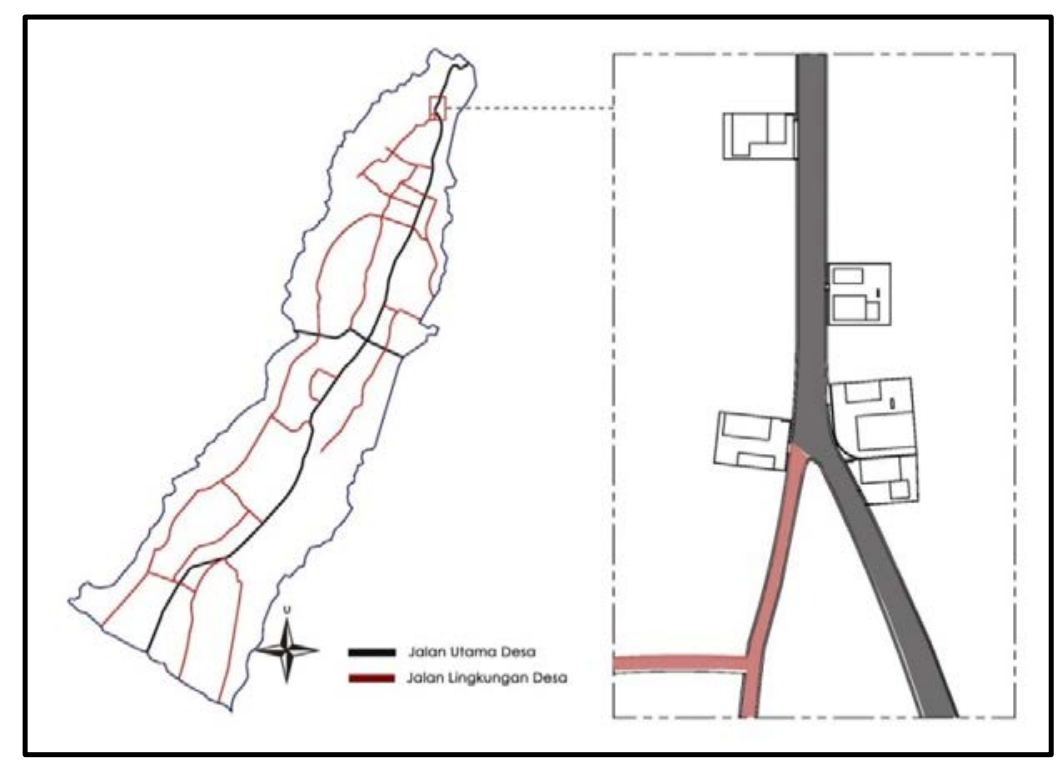

Gambar 8. Denah Letak Rumah Masyarakat Katolik di Desa Canggu

Rumah masyarakat Katolik yang memiliki natah yang letaknya di tengah pekarangan, ruang seperti Gua Bunda Maria, bale, dan dapur akan menghadap ke arah natah. Variasi lain yaitu ruang terbuka tidak berada tepat di tengah pekarangan, antara lain natah yang berada di kelod, kauh, kaja dan kangin, ruang 
yang lain akan mengikuti keadaan orientasi ruang hunian. Hal tersebut disebabkan oleh bentuk lahan, sehingga natah berada di dekat jalan (Gambar 8).

\subsection{Hubungan antar Ruang Tempat Tinggal Masyarakat Bali Katolik di Desa Canggu}

Setiap bangunan didalam pekarangan tersebut mempunyai fungsi ruang yang berbeda-beda. Rumah masyarakat Bali Katolik di Desa Canggu memiliki satu ruang yang memiliki level ketinggian bangunan yang lebih tinggi dan biasanya terbuka pada salah satu sisinya. Maka ruang tersebut akan dijadikan pusat atau tempat pelaksanaan ibadah oleh masyarakat Katolik di Desa Canggu. Selanjutnya natah akan difungsikan untuk masyarakat yang ikut dalam kegiatan peribadatan maupun sosial yang dilaksanakan.

Sirkulasi di dalam ruang tuan rumah yang terjadi pada pekarangan rumah ketika penghuni ingin meninggalkan pekarangan adalah sirkulasi linier. Penghuni yang akan keluar dari pekarangan umumnya pergi ke Goa Bunda Maria untuk memanjatkan doa memohon keselamatan kemudian menuju garase jika ingin pergi menggunakan kendaraan ataupun penghuni akan langsung menuju gerbang rumah. Jika penghuni datang dari luar area pekarangan maka sirkulasinya adalah radial dimana penghuni akan masuk lewat gerbang rumah lalu masuk dan menyebar sesegala sisi dari pekarangan tersebut tanpa harus pergi ke satu titik terlebih dahulu (Gambar 9).

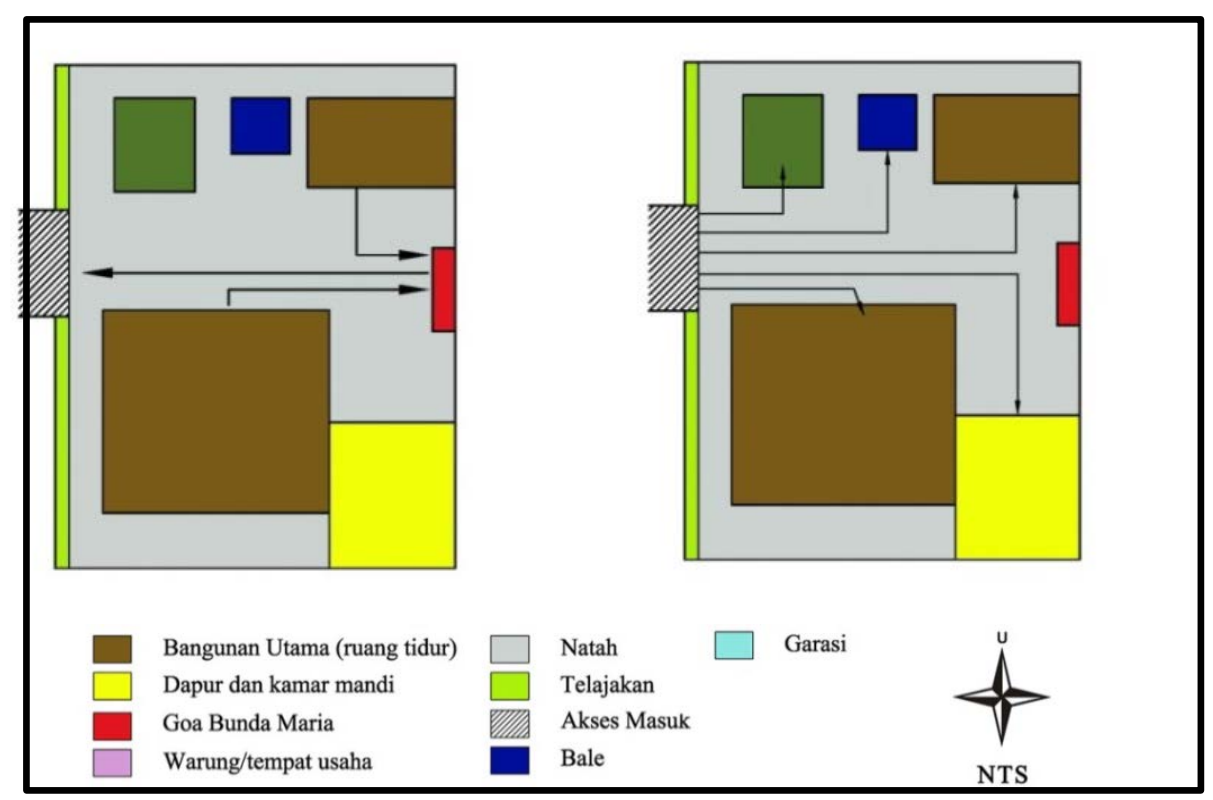

Gambar 9. Sirkulasi Manusia pada Rumah Tinggal Masyarakat Bali Katolik di Desa Canggu

\section{Simpulan}

Desa Canggu adalah sebuah kelurahan yang memilikin tujuh Banjar adat dan didalamnya terdapat salah satu komunitas masyarakat Katolik terbesar di Bali tepatnya di Banjar Padang Tawang dan Babakan. Umat Katolik di Desa Canggu berperan penting dalam upaya menumbuhkembangkan hubungan antaragama seperti merekatkan hubungan kekerabatan antar umat, tidak hanya yang beragama Katolik, tetapi juga seluruh umat beragama.

Salah satu upaya yang dilakukan adalah pertemuan kebudayaan antara Hindu Bali dan Katolik. Kedua kebudayaan ini mengalami proses inkulturasi dimana terjadi peleburan kebudayaan tanpa menghilangkan budaya asli komunitas yang lain. Hal ini dapat dilihat dari ruang rumah Masyarakat Katolik di Desa Canggu yang bagi berdasarkan: (1) letak (setting) yang tiap bangunannya tidak terdiri dari satu atap seperti rumah tradisional Bali, namun tidak mengadaptasi petelakan ruang sanga mandala, (2) tingkatan (hierarchy) yang mengadaptasi konsep tri mandala kedalam fungsi liturgial penataan ruang dan bentuk arsitektur gereja Katolik, dan (3) arah (orientation) sedikit ada perbedaan karena hampir semua rumah masyarakat Katolik menghadap kearah jalan utama yang berbeda dengan Arsitektur Bali dimana seluruh bangunan menghadap kearah natah atau tengah. 


\section{Daftar pustaka}

Aler, I. G.(1983). Butir-butir Tercecer tentang Adat Bali. Denpasar: Bali Agung.

Anonim. (2011).Perjalanan Hidup Iman Umat Katolik Proki Roh Kudus Babakan. Canggu: Tidak diterbitkan.

Bappeda Tingkat I Bali dan Universitas Udayana.(1982). Pengembangan Arsitektur Tradisional Bali untuk Keserasian Alam Lingkungan, Sikap Hidup, Tradisi dan Teknologi. Denpasar: Bappeda Tingkat I Bali.

Budihardjo, E. (1998). Percikan Msalah Arsitektur Perumahan Perkotaan. Yogyakarta: Gadjah Mada University Press.

Koentjaraningrat. (2002). Pengantar IImu Antropologi. Jakarta: PT. Rineka Cipta.

Srisadono, Y. D. (2012). Melintas: Konsep Sacred Space dalam Arsitektur Gereja Katolik. Bandung: Depertement of Architecture Parahyangan Catholic University. 